INEL-96/0148

\title{
Technical Requirements Document for the Waste Flow Analysis
}

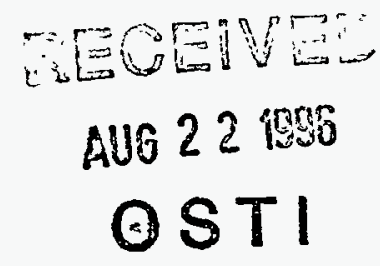

David E. Shropshire

May 1996

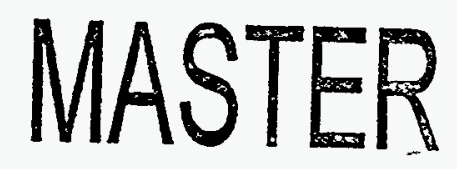

चै Lockheed
Idaho Technologies company 


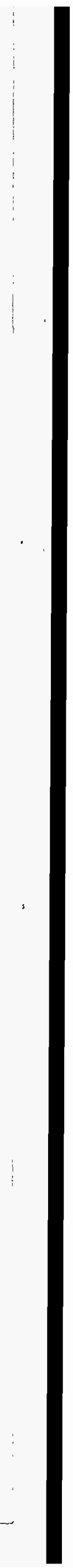




\section{Technical Requirements Document for the Waste Flow Analysis}

David E. Shropshire

\section{Idaho National Engineering Laboratory}

Lockheed Martin Technologies

Idaho Falls, Idaho 83415

Prepared for the

U.S. Department of Energy

Assistant Secretary for Environmental Management

Under DOE Idaho Operations Office

Contract DE-AC07-94ID13223 



\section{DISCLAIMER}

Portions of this document may be illegible in electronic image products. Images are produced from the best available original document. 



\section{DISCLAIMER}

This report was prepared as an account of work sponsored by an agency of the United States Government. Neither the United States Government nor any agency thereof, nor any of their employees, makes any warranty, express or implied, or assumes any legal liability or responsibility for the accuracy, completeness, or usefulness of any information, apparatus, product, or process disclosed, or represents that its use would not infringe privately owned rights. Reference herein to any specific commercial product, process, or service by trade name, trademark, manufacturer, or otherwise does not necessarily constitute or imply its endorsement, recommendation, or favoring by the United States Government or any agency thereof. The views and opinions of authors expressed herein do not necessarily state or reflect those of the United States Government or any agency thereof. 



\section{Contents}

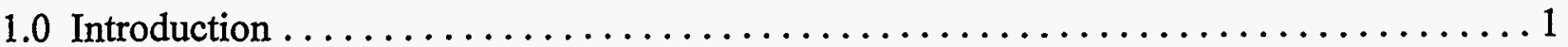

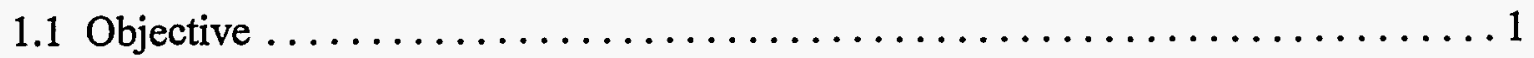

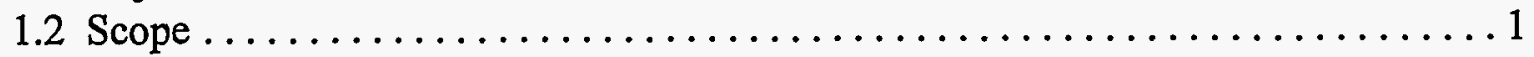

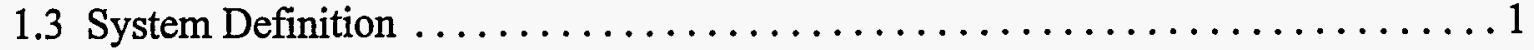

1.4 Top-Level Functional Features . . . . . . . . . . . . . . . . . . . . . . 3

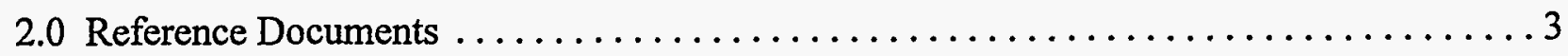

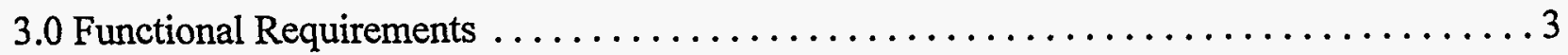

3.1 Top-Level System Requirements (customer expectations) $\ldots \ldots \ldots \ldots \ldots \ldots . . \ldots$

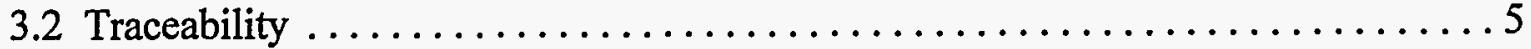

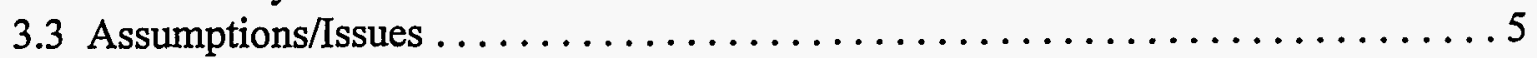

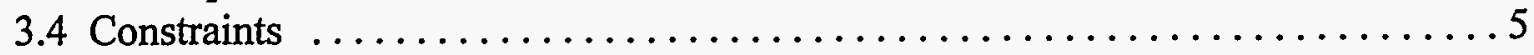

3.5 Requirements Allocated (flowed-down to cost, risk, \& waste flow segments) $\ldots \ldots 6$

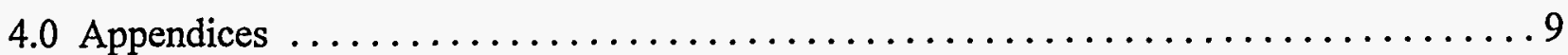

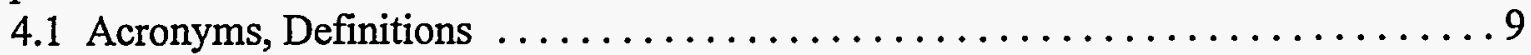





\section{Technical Requirements Document \\ for the Waste Flow Analysis}

\subsection{Introduction}

The purpose of this Technical Requirements Document (TRD) is to define the top level customer requirements for the Waste Flow Analysis task. These requirements [once agreed upon with the Department of Energy (DOE)] will be used to flow down subsequent development requirements to the model specifications. This document is intended to be a "living document" which will be modified over the course of the execution of this work element. Initial concurrence with these technical functional requirements from Environmental Management (EM)-50 is needed before the Work Plan can be developed.

\subsection{Objective}

Have a sound technical basis for funding EM-50 research and development studies. Provide consistent basis for evaluations considering all aspects of a technology and its life-cycle costs and health and safety risks. Identify incentives for investment in research and development (R\&D), the cost savings that can be realized, the risk reduction possible, and the specific $R \& D$ programs that should be conducted for the future.

\subsection{Scope}

Develop a tool(s) that will help EM-50 evaluate impacts to waste flows, cost, and risk for various postulated waste management scenarios with emphasis on identifying the opportunities (economic incentives, risk reduction) for technology development.

\subsection{System Definition}

Complete operating systems that cover all waste management activities from the time waste is received ${ }^{1}$ from a generator until all waste is properly disposed. The initial system would support (alpha and non-alpha) mixed low-level waste (MLLW). The initial system could be expanded to include (mixed, non-mixed, remote-handled) transuranic waste (TRU) and (alpha, non-alpha, remote-handled) low-level waste (LLW). The systems required for managing the three different waste type's (MLLW, LLW, TRU) classifications are significant enough to warrant three distinct definitions. Potentially the systems could be integrated together after initial development. Additionally, systems including high-level waste (HLW) and spent nuclear fuel (SNF) could be developed.

\footnotetext{
${ }^{1}$ Waste could be received from an EM-30 operating treatment facility, or from EM-40/60 activities. This system definition does not include EM-40/60 preparation and shipment of wastes to EM-30.
} 
The MLLW, LLW, TRU, HLW, and SNF waste (material) systems are described at a high-level to define the system boundaries. The system descriptions define (in a physical sense) what is to be modeled. The system definitions include the waste (material) to be managed, site conditions, existing and planned facilities, characterization systems, processing systems, packaging systems, transportation, storage, and disposal. New technology systems are also identified within the system descriptions. The system description for the waste (material) systems are further defined as follows:

\section{MLLW (Fiscal Year (FY)-96)}

- multiple (generic) sites [e.g., western site (Idaho National Engineering Laboratory (INEL), eastern sites (Oak Ridge National Laboratory (ORNL) or Savannah River Site (SRS)];

- $\quad$ legacy waste inventories (based on Mixed Waste Inventory Report (MWIR) data);

- variable waste generation (from EM-30, EM-40, EM-60);

- $\quad$ pre-treatment storage;

- transportation from generators to centralized/regionalized facilities;

- thermal and non-thermal treatment systems (10 selected Integrated Thermal Treatment Study (ITTS) and Integrated Non-Thermal Study (INTS) technologies), including various final waste forms;

- . expanded treatment systems to include the five major ITTS/INTS subsystems;

- $\quad$ post treatment storage;

- $\quad$ transportation to disposal (road, rail);

- disposal systems (shallow land, engineered disposal).

\section{MLLW (enhanced), LLW, TRU (Propose FY-97)}

- $\quad$ expanded site locations (up to $49 \mathrm{DOE}$ sites with mixed waste inventories);

- $\quad$ updated legacy inventories (based on MWIR '95);

- $\quad$ retrieval of stored waste;

- $\quad$ combined MLLW, LLW, TRU waste processing volumes;

- $\quad$ additional ITTS/INTS treatment systems (e.g., portable);

- $\quad$ additional subsystems (e.g., alternative characterization technologies);

- $\quad$ hybrid ITTS/INTS treatment systems;

- $\quad$ existing and planned major site systems (inc. pre-treatment, treatment, storage, and disposal technologies), schedules, processing rates and capacities;

- $\quad$ expanded storage systems (long term storage);

- TRU waste packaging systems;

- TRU transportation;

- $\quad$ expanded disposal systems (Waste Isolation Pilot Plant (WIPP) - TRU waste).

\section{HLW (Propose FY-98)}

- all current DOE high-level waste found at Hanford, West Valley, Savannah River, and the INEL;

- $\quad$ existing and planned major site systems (inc. current tank storage, treatment, 


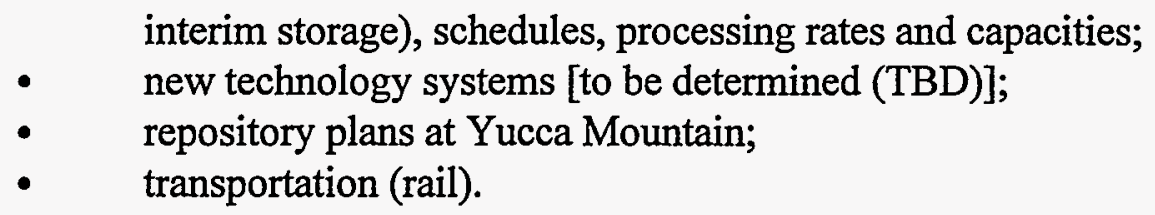

SNF (Propose FY-98)

- $\quad$ all current DOE spent nuclear fuel at Hanford, INEL, Savannah River, Oak Ridge;

- $\quad$ existing and planned storage facilities (wet and dry), schedules, capacities;

- transportation (rail), schedules;

- $\quad$ new technology systems (TBD);

- repository plans at Yucca Mountain.

\subsection{Top-Level Functional Features}

The model will be developed to estimate: total life-cycle costs for postulated waste management scenarios, timing and cost savings opportunities for new technology systems, economic trade-offs between comparable alternatives, waste flows and volumes, and determination of relative technology system risks.

\subsection{Reference Documents}

Mixed Waste Inventory Report 1995

Federal Facilities Compliance Act Site Treatment Plans

Baseline Environmental Management Report (BEMR) site plans

BEMR System Cost Model Calibration Report

Waste Management Programmatic Environmental Impact Statement

ITTS and INTS Technical reports

Simplified Health and Safety Risk Approach

\subsection{Functional Requirements}

3.1 Top-Level System Requirements (customer expectations) ${ }^{2}$.

1. Waste Flow Analysis/Scheduling

1.1 Provide quick interactive analysis of the effects of mass flow over time on EM's capability to discharge its responsibilities for managing nuclear waste.

${ }^{2}$ These functional requirements would be integrated into the work scope during the entire period of performance. Capabilities would be mapped to the customers requirements for each program phase of model development. 
1.2 Summarize impacts of acceleration, delay, elimination of actions associated with the various waste types (i.e., waste generation, pretreatment storage, treatment work-off, shipping, disposal).

1.3 Provide ability to integrate commercial treatment, storage, and disposal costs.

\section{Life-Cycle Cost Analysis}

2.1 Provide current year dollar life-cycle treatment technology cost comparisons including pre-operations, construction, operations and maintenance, decommissioning and decontamination (D\&D).

2.2 Include transportation costs (road, rail).

2.3 Include storage and disposal costs including surveillance and maintenance.

2.4 Ability to vary technology system and sub-system cost scaling factors.

3. Health and Safety Risk Analysis

3.1 Discriminate between relative ITTS/NNTS technology risk differences.

3.2 Differentiate risk for various waste forms (grout, polymer, glass).

3.3 Differentiate risk of transportation (road, rail).

3.4 Define risk differences due to types of disposal in combination with various waste forms.

3.5 Define risk of waste storage, including long-term disposal.

4. Other Performance Measures

4.1 Ability to integrate hard factors (e.g., regulations, Batt agreement).

4.2 Ability to integrate soft factors (e.g. socio-economic, political, public perception).

5. Waste Analysis

5.1 Ability to analyze one waste type at a time or multiple waste types concurrently. Allow consolidation of waste volumes of alpha MLLW/LLW and TRU.

5.2 Expanded cost/capacity range of new systems to allow for variable waste generation from EM-40/60.

6. Technology Performance

6.1 Accommodate technology flow sheets specifying mass/volume changes, secondary waste generation, splitting of waste streams to multiple 
processing functions, etc.

6.2 Provide analysis of new technology systems (e.g. ITTS, INTS, portable, etc.) and hypothetical treatment systems.

6.3 Provide capability to vary front-end pre-processing sub-systems and disposal options (existing shallow land, new RCRA disposal, engineered disposal).

6.4 Define technology performance specifications required to achieve desired outputs.

6.5 Compare regional vs. centralized applications of treatment systems.

\subsection{Traceability}

The Technical Requirements Document will be used to provide downward and upward traceability of requirements to the Work Plan and the model specifications.

\subsection{Assumptions/Issues}

1) Modeling development will be performed through a versatile, expandable programming environment, which will facilitate spiral requirements development. Close coordination will be required between the software developers and the users.

2) This system will be provided as a comprehensive stand-alone model, integrating cost, waste flow, and health and safety risk.

3) The system will be designed as a totally integrated, "user friendly," fully documented system.

4) The system can be run by non-technical, non-computer users.

5) Due to small waste volumes and/or small costs, the system will not include the following wastes: greater-than-Class C (GTCC), sanitary, hazardous.

6) The technical basis for the health and safety risk analysis capability will be based on the work performed and evaluated by the Lockheed Idaho Technologies Company (LITCO) Environmental Management Integration Program.

7) Directly utilize and be consistent with the MWIR waste matrix categories.

\subsection{Constraints}

1) Work Element funding limitations may limit system development in FY-96. After this Technical Requirements Document for the system is established with EM-50, then the specific tasks and funding requirements for system development will be defined.

The recommended development approach is to first integrate and enhance the existing codes that have been developed for MLLW. This approach would allow integration of seven ITTS and three INTS technologies into the system in FY-96. 
LITCO anticipates that significant analysis capabilities can be developed in FY96, based on the model development already completed for EM-30. After successful development of the initial waste systems, the system could be expanded to include other waste types.

3.5 Requirements Allocated (flowed-down to cost, risk, \& waste flow segments) 


\section{Functional System Requirements:}

\section{Cost Segment}

1) Allow variation in operating efficiencies (availability, years of operation). Include capability to manipulate hypothetical new technology treatment systems.

2) Include ITTS/INTS treatment system optimization capabilities (waste matrix type, process flows, splitters, effluents, volume reduction, reduction in pre-treatment and sorting steps).

3) Capability to provide comparative commercial cost equivalent evaluations.

4) Allow independent selection of treatment and disposal technologies. Include shallow land and engineered disposal options.

5) Allow consolidation of waste volumes of alpha MLLW/LLW and TRU. Include new technology processing systems.

6) Include site waste data and projections for Environmental Restoration (ER) and D\&D wastes.

7) Include existing major site's treatment, storage, and disposal facilities with related capacities and availability.

8) Include ability to perform present economic analysis using the present worth analysis.

\section{Questions Supported:}

\section{Cost Segment}

1) What operating parameters significantly affect the life-cycle costs? How can new technologies be operated more efficiently?

2) What can be done to the ITTS/INTS technologies to improve their performance? How much cost savings would be associated with reduced primary and secondary treatment effluents? What are the system cost differences between ITTS and INTS systems under various operating conditions?

3) How would commercial processing using new technologies compare to $\mathrm{DOE}$ processing?

4) What combinations of treatment technologies and disposal options are most cost effective? What cost savings in disposal could be achieved using vitrified waste forms?

5) What are the cost advantages of combined processing of alpha wastes? How much additional cost would be required to treat mixed TRU to land disposal restriction vs. treatment to WIPP waste acceptance criteria?

6) How do results change when actual site waste streams and ER/D\&D wastes are used? How can new technologies be optimized to support the larger new waste streams?

7) How much of the waste loads from EM-40/60 can be accommodated by existing facilities and how can modifications be made to increase this capacity?

8) How would future treatment using new technologies compare to early treatment using conventional technologies on a present worth cost basis (accounting for the time value of money)? What is the R\&D payback? 


\section{Functional System Requirements:}

\section{Risk Segment}

1) Develop relative risk capability in combination with life-cycle cost capabilities.

2) Integrate the ITTS/INTS systems into the risk model. Allow model manipulation equivalent to cost analysis for the performance of system optimization.

3) Integrate the cost/risk functions for each of the system studies. Implement the cost/risk sensitivity analysis capability. Produce risk output by system and sub-system elements.

4) Incorporate risk relationships for long-term storage (repackaging, characterization, etc.).

5) Incorporate risk factors and algorithms for commercial processing.

\section{Functional System Requirements:}

\section{Waste Flow Segment}

1) Develop waste flow analysis capabilities for existing and proposed treatment options.

2) Include in the system data base the details on waste inventories and generation rates.

3) Develop simulation module to address disposal and transportation issues.

4) Incorporate site planning basis into system.

\section{Questions Supported:}

\section{Risk Segment}

1) Which waste forms produce the least long-term public risk for storage and disposal? How do we maximize risk reduction for every dollar spent on R\&D?

2) How do the ITTS/INTS systems perform from a relative risk standpoint under different operating conditions (waste loads, scheduling, disposal options, transportation, etc.)?

3) What is the difference in the relative worker and disposal risk between systems? What are the cost/risk tradeoffs? Where are the great opportunities for risk reduction using new technologies (thermal and nonthermal)? What are the most cost effective ways to reduce risk?

4) How would the risks compare for long-term storage prior to treatment versus the current planning basis?

5) How would risk compare for on-site DOE versus private sector treatment?

\section{Questions Supported:}

\section{Waste Flow Segment}

1) What impacts do various treatment technologies have on waste flows and treatment schedules?

2) What storage capacities and throughputs are required for the existing and new technology systems?

3) What impacts do non-technical issues, such as siting of disposal facilities, transportation routes, have on new waste treatment technologies?

4) What capacities should new facilities be designed for? When do new facilities need to be built, and what technology functions do they need to include? 


\subsection{Appendices}

$\begin{array}{ll}\text { 4.1 Acronyms, Definitions } \\ \text { BEMR } & \begin{array}{l}\text { Baseline Environmental Management Report } \\ \text { decommissioning and decontamination }\end{array} \\ \text { D\&D } & \text { Department of Energy } \\ \text { DOE } & \text { Environmental Management } \\ \text { EM } & \text { Environmental Restoration } \\ \text { ER } & \text { fiscal year } \\ \text { FY } & \text { greater-than-Class C } \\ \text { GTCC } & \text { high-level waste } \\ \text { HLW } & \text { Idaho National Engineering Laboratory } \\ \text { INEL } & \text { Integrated Non-Thermal Study } \\ \text { INTS } & \text { Integrated Thermal Treatment Study } \\ \text { ITTS } & \text { Lockheed Idaho Technologies Company } \\ \text { LITCO } & \text { low-level waste } \\ \text { LLW } & \text { mixed low-level waste } \\ \text { MLLW } & \text { Mixed Waste Inventory Report } \\ \text { MWIR } & \text { Oak Ridge National Laboratory } \\ \text { ORNL } & \text { research and development } \\ \text { R\&D } & \text { spent nuclear fuel } \\ \text { SNF } & \text { Savannah River Site } \\ \text { SRS } & \text { to be determined } \\ \text { TBD } & \text { Technical Requirements Document } \\ \text { TRD } & \text { transuranic waste } \\ \text { TRU } & \text { Waste Isolation Pilot Plant } \\ \text { WIPP } & \end{array}$


